\title{
NITRATE POLLUTION IN THE COASTAL AQUIFER SYSTEM OF THE KORINTHOS PREFECTURE (GREECE)
}

\section{K. VOUDOURIS ${ }^{1, *}$, \\ A. PANAGOPOULOS ${ }^{2}$, I. KOUMANTAKIS 3}

\author{
${ }^{1}$ Lab. of Engineering Geology and Hydrogeology, \\ Dept. of Geology, Aristotle University of Thessaloniki \\ ${ }^{2}$ National Agricultural Research Foundation, \\ Land Reclamation Institute, 57400, Sindos, Greece \\ ${ }^{3}$ Section of Applied Geology, \\ Department of Mining and Metallurgical Engineering, \\ National Technical University of Athens, \\ Heroon Polytechniou 9, 15780, Zografou, Greece. \\ * to whom all correspondence should be addressed: \\ Tel: + (30) 2310-998519 \\ Fax: + (30) 2310-998530 \\ e-mail: kvoudour@geo.auth.gr
}

Received: 9/10/02

\begin{abstract}
Over the last decades intensified agricultural production is applied in the northern coastal part of Korinthos Prefecture (Peloponnese, Greece). An aquifer system occurs in the recent basin deposits, which consists of unconsolidated material, namely sands, pebbles and fine clay to silty sand sediments. A network of production boreholes and wells distributed over the studied region were sampled in June 1998 and the waters analyzed for major ions, nitrites and ammonia. Quality deterioration was detected and attributed by crop overfertilization and use of abandoned shallow wells as septic tanks, inducing increased nitrogen compound concentrations. Nitrates are noticeable throughout the entire region rendering most of the analyzed waters improper for human consumption, as concentrations by far exceed $50 \mathrm{mg} \mathrm{l}^{-1}$. Mean nitrate concentration in the groundwater is $74 \mathrm{mg} \mathrm{l}^{-1}$ and the standard deviation 72 . In general, low nitrate concentrations were observed in wet seasons.
\end{abstract}

KEYWORDS: Groundwater, Nitrates, Pollution, Korinthos, Greece

\section{INTRODUCTION}

Nitrate is the main form of $\mathrm{N}$ in groundwaters. Several authors (Hill, 1982; Pacheco and Cabrera, 1997; Steinich et al., 1998; Daskalaki et al., 1998; Antonakos and Lambrakis, 2000) have related groundwater nitrates to different sources such as leaching of organic and inorganic fertilizers, animal waste, domestic effluents and industry.
Fertilizers are considered to be the principal source in the intensively cultivated areas. The amount of nitrate that leaches from agricultural lands is influenced by natural factors such as the soil type and climatic conditions (Mikkelsen, 1992).

The northeastern part of the Korinthos Prefecture between the towns of Korinth and 


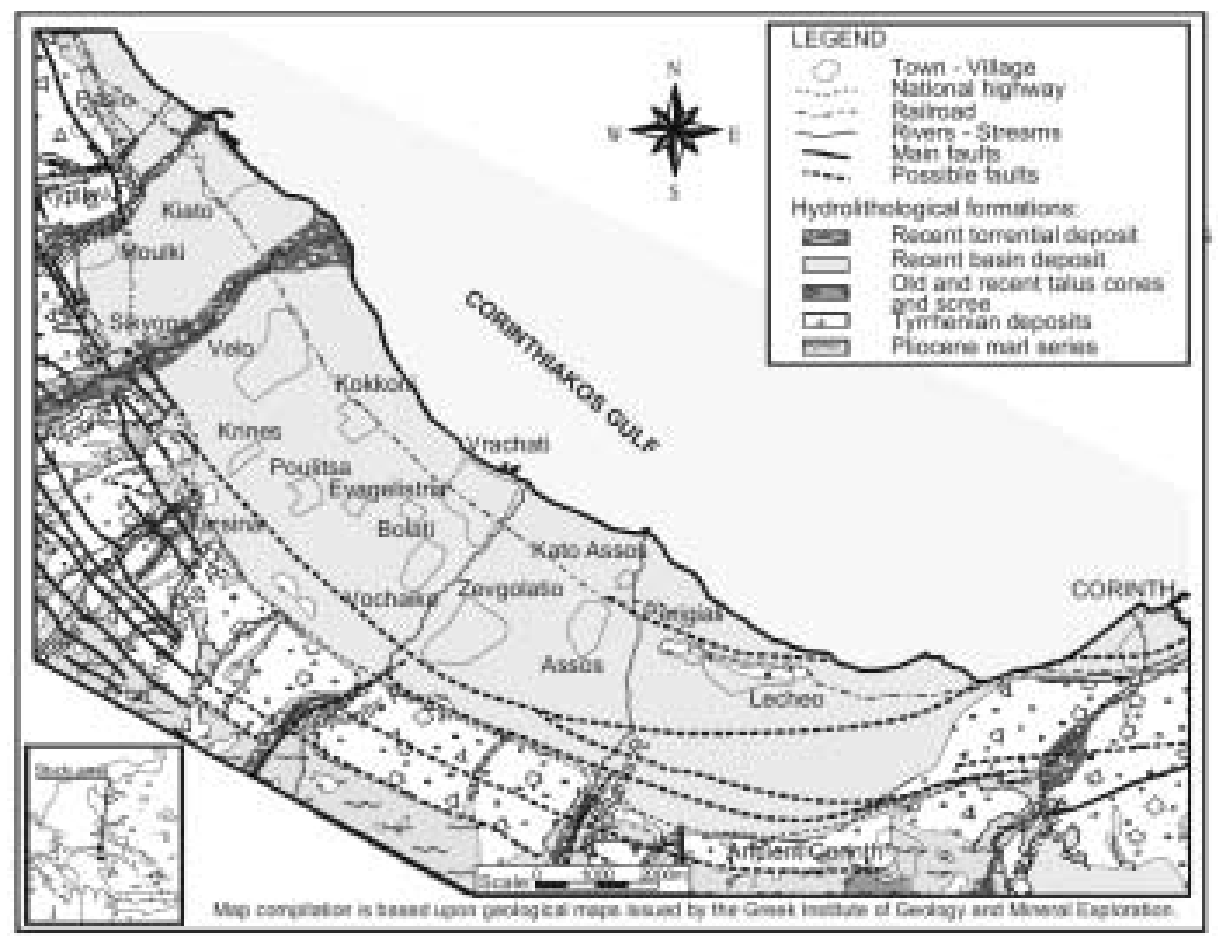

Figure 1. Geological map of the study area

Kiato known as Vocha plain, is a fast growing one where about $55 \%$ of the total population is concentrated thus attracting most of its socio-economic activities. The population has increased by $36 \%$ between 1971 and 2001. In a large part of the area $\left(45 \mathrm{~km}^{2}\right)$ irrigated agriculture is practiced during the last decades. The land is used mainly for the cultivation of vineyards, citrus fruits, olives and apricots.

Municipal wastewater is generally collected in septic tanks, contributing to groundwater contamination. Central municipal sewage-treatment systems do not exist in the central part of the region.

Average annual rainfall is $473 \mathrm{~mm}$, most of which occurs during the rainy season between November-April, and the mean annual temperature is $17.5^{\circ} \mathrm{C}$.

The study area is characterized by increasing trend in water consumption, as a result of intensive urbanization, tourist development and irrigated land expansion. Water demands have considerably increased over the last 20 years and are mainly covered by groundwater abstracted from the alluvial aquifer system via wells and boreholes in excess of 1000 and partly by the discharge of the river Asopos. Groundwater over-exploitation is evident by the constant groundwater heads decline.

At the Vocha plain groundwater pollution is documented and is attributed to agricultural activities and disposal of sewage in septic tanks (Daskalaki et al., 1998). Surface water quality deterioration is also apparent and is mainly attributed to the uncontrollable discharge of untreated olive oil mill effluent (Voudouris et al., 2000a).

In this paper the distribution and variation of groundwater nitrate pollution is presented. The results concluded can be used in realizing a rational groundwater management policy in order to minimize the negative anthropogenic impact on the coastal aquifer of Korinthos Prefecture.

\section{GEOLOGY AND HYDROGEOLOGY}

The plain, north of the national highway, is formed of recent unconsolidated material consisting of sands, pebbles, breccias and fine clay to silty sand deposits (Koumantakis et al., 1999; Panagopoulos et al., 2001). Lateral continuity of the afore described deposits is disrupted by recent and older fluvio-torrential deposits originating from the streams-rivers that flow across the studied region, as illustrated in the geological map of Figure 1. South of the national highway, which 
bounds the studied region, the tyrrhenian deposits of coastal origin crop out. Usually, they consist of highly consolidated breccio-conglomerates, sand, small gravel and sporadically marl intercalations. The Pliocene deposits of the marl series occupy most of the hilly region further south of the studied region and form the bedrock of the studied aquifer system. Within this formation sandstone, consolidated gravel, conglomerates and marly limestones of lacustrine origin exist in locally restricted intercalations. The thickness of the plain's deposits varies from $30 \mathrm{~m}$ to 70 $\mathrm{m}$, whilst along the fluvio-torrential deposits of the river Asopos it exceeds $100 \mathrm{~m}$. As a result of their origin the deposits are characterized by high degree of heterogeneity and anisotropy.

From a hydrogeological point of view the system consists of an unconfined phreatic aquifer superimposed on successive confined or semi-confined aquifers. Within the secluded thyrrenian conglomerate blocks overhanging aquifers of low potential may develop. Despite the documented heterogeneities however, it is suggested that on a regional scale a uniform aquifer may be considered on the basis that observed lithological anomalies are not extensive and most groundwater level measurements are indicative of a single piezometric surface.

Depth to groundwater ranges between 1-18 m from the ground surface, it receives its lowest values in the southern parts of the region and progressively increases southwards. Groundwater flow direction is from South toward the coast. Mean hydraulic gradient as measured from the compiled piezometric maps is $\mathrm{i}=0.006$.

Groundwater recharge occurs mainly in the forms of precipitation and riverbed infiltration. Lateral inflow from the fluvio-torrential deposits and from the tyrrhenian deposits across the southern edge of the basin is essential to the system's replenishment. Returns from flood irrigation, which is traditionally practiced in the region, play also a key role in the aquifer's recharge. A negative groundwater balance is established in the studied area, which reaches some $4.7 \times 10^{6} \mathrm{~m}^{3} /$ year, triggering seawater intrusion, which has negative consequences for the development of the region (Panagopoulos et al., 2002).

The hydraulic properties of the aquifer system range within a large scale of values, as determined from extensive pumping test analyses.

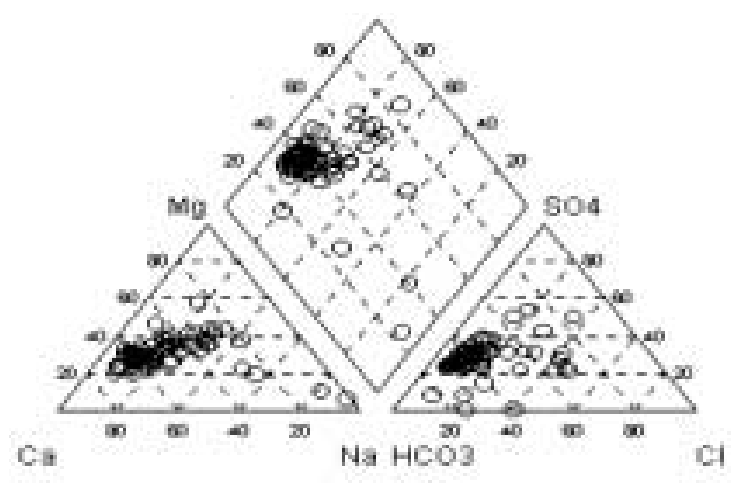

Figure 2. $\quad$ PIPER diagram (June 1998)

Transmissivity and storage coefficient values vary between $\mathrm{T}=2 \times 10^{1}-9 \times 10^{2} \mathrm{~m}^{2} \mathrm{~d}^{-1}$ and $\mathrm{S}=0.2-5 \times 10^{-2}$ respectively in the fluvio-torrential deposits and $\mathrm{T}=2-8 \times 10^{1} \mathrm{~m}^{2} \mathrm{~d}^{-1}$ and $\mathrm{S}=0.1-5 \times 10^{-5}$ respectively in the finer deposits (Koumantakis et al., 1999; Hionidi et al., 2001).

\section{HYDROCHEMISTRY}

Sixty-nine groundwater samples collected from boreholes and dug wells in June 1998, were analysed for major ions, nitrites and ammonia. Sampling points are shown in Figure 4. The equipment of the National Technical University of Athens, Section of Geological Sciences, facilitated laboratory determinations. Electrical conductivity (EC), and $\mathrm{pH}$ were also measured in situ. Analyses of nitrate were completed by the spectrum photometry method.

Seasonal variation of nitrates as deduced by the study of preceding sampling periods were also considered (Panagopoulos et al., 2001).

The average, minimum and maximum values of major ions of groundwaters in the study area are presented in Table 1. Taking into account the data of Table 1, the following conclusions can be drawn.

The coefficient of variation shows clearly the wide dispersion of $\mathrm{NH}_{4}, \mathrm{~K}, \mathrm{N \alpha}, \mathrm{Cl}, \mathrm{NO}_{2}$.

The average $\mathrm{pH}$ of groundwater is 7.23 , thus indicating a slightly alkaline type. Electrical conductivity varies between $778-5340 \mu \mathrm{S} \mathrm{cm}^{-1}$ and this is probably indicative of saline intrusion along the coastal areas of the studied system. It generally increases eastwards and reaches its peak at the Lecheo area. The average value of Total Dissolved Solids (TDS) is high at $1001 \mathrm{mg} \mathrm{l}^{-1}$ and exhibits significant local variation. Highest conductivity and TDS values are related to seawater 
Table 1. Analyses ( $\left.\mathrm{mg} \mathrm{l}^{-1}\right)$ of water samples (June 1998)

\begin{tabular}{|c|c|c|c|c|c|}
\hline $\begin{array}{c}\text { Chemical } \\
\text { parameters }\end{array}$ & $\begin{array}{c}\text { Mean value } \\
(\boldsymbol{\mu})\end{array}$ & $\begin{array}{l}\text { Minimum } \\
\text { Value }\end{array}$ & $\begin{array}{c}\text { Maximum } \\
\text { Value }\end{array}$ & $\begin{array}{c}\text { Standard } \\
\text { deviation } \\
(\sigma)\end{array}$ & $\begin{array}{c}\text { Coefficient } \\
\text { of variation } \\
\qquad(\sigma / \mu)\end{array}$ \\
\hline pH & 7.23 & 6.68 & 8.2 & 0.37 & 0.04 \\
\hline E.C. $\left(\mu \mathrm{S} \mathrm{cm}^{-1}\right)$ & 1564 & 778 & 5340 & 732 & 0.46 \\
\hline $\mathrm{O}_{2}$ & 3.74 & 0.43 & 6.95 & 1.62 & 0.43 \\
\hline O (\%) & 40.1 & 4.8 & 72 & 18.2 & 0.45 \\
\hline T.H. & 675 & 80 & 2454 & 325 & 0.48 \\
\hline T.D.S. & 1001 & 443 & 4205 & 551 & 0.55 \\
\hline $\mathrm{Ca}$ & 155 & 8 & 366 & 48.6 & 0.31 \\
\hline Mg & 69 & 14.5 & 369 & 57.2 & 0.83 \\
\hline $\mathbf{N a}$ & 96.5 & 20 & 490 & 106 & 1.09 \\
\hline $\mathbf{K}$ & 13 & 1 & 82 & 16 & 1.76 \\
\hline $\mathrm{HCO}_{3}$ & 497 & 217 & 924 & 98.7 & 0.19 \\
\hline Cl & 112 & 23 & 725 & 135 & 1.20 \\
\hline $\mathrm{SO}_{4}$ & 232 & 0 & 1450 & 207 & 0.89 \\
\hline $\mathrm{NO}_{3}$ & 74 & 1.2 & 524 & 72 & 0.97 \\
\hline $\mathrm{NO}_{2}$ & 0.045 & 0.0001 & 0.66 & 0.063 & 1.4 \\
\hline $\mathrm{NH}_{4}$ & 0.32 & 0.0 & 8.0 & 0.96 & 3.0 \\
\hline SAR & 1.84 & 0.36 & 23.4 & 3.20 & 1.73 \\
\hline
\end{tabular}

intrusion, as a result of the intensified exploitation (Panagopoulos et al., 2001). The mean value of Total Hardness (TH) exceeds in most of the samples the value of $300 \mathrm{mg} \mathrm{l}^{\mathbf{1}}$ in $\mathrm{CaCO}_{3}$, thus groundwater is classified as very hard.

Mean chloride concentration in the groundwater is $112 \mathrm{mg} \mathrm{l}^{-1}$ and the standard deviation 135 . The distribution of chlorides shows a general increase of the concentration down gradient, to the north towards the coastal line. In addition to this trend, statistical analysis carried out exhibits a general increase of the chloride concentrations to an eastwards direction. High values are related to seawater intrusion, due to over exploitation (Voudouris et al., 2000b).

A trilinear plot (Piper diagram) shown in Figure 2 , indicates variability in water types. Calcium and bicarbonate are the predominant ions in fresh waters near the recharge zones of the aquifer system. This type of water occurs along the southern and especially the southwestern part of the studied area.

$\mathrm{A} \mathrm{Na}^{+}-\mathrm{HCO}_{3}^{-}$to $\mathrm{Na}^{+}-\mathrm{SO}_{4}^{2-}$ type of water, which is apparent downstream of the recharge zones, along the central-coastal parts of the region, denotes excessive mixing and ion exchange processes and possibly saline water intrusion (Panagopoulos et al., 2001).

\section{NITRATE POLLUTION}

Intensification of agricultural activities along with the lack of proper education of the farmers and supervision by the regulatory authorities has often resulted in significant over-fertilization of crops to ensure maximum productivity. Both organic, including manures, and inorganic fertilisers are used in the region, the latter being most popular.

Commonly, $\left(\mathrm{NH}_{4}\right)_{2} \mathrm{SO}_{4}$, phosphate and potash are applied. $\mathrm{K}^{+}$from potash fertilisers and $\mathrm{PO}_{4}^{3-}$ from phosphate fertilisers are absorbed into the soil (Rao et al., 1997). Through a nitrification processes in the presence of oxygen, ammonium is transformed into nitrates according to the following reaction (Freeze and Cherry, 1979):

$2 \mathrm{O}_{2}+\mathrm{NH}_{4}^{+} \rightarrow \mathrm{NO}_{3}^{-}+2 \mathrm{H}^{+}+\mathrm{H}_{2} \mathrm{O}$

In the study area, depending on the type of cultivations, the rates of nitrate fertiliser applied per hectare of agricultural area are between $35-65 \mathrm{~kg}$ ha $^{-1}$. 
A great number of septic tanks, which collects domestic wastewater, also contribute to groundwater quality deterioration.

Nitrate generally moves in soil and groundwater with no transformation, and hence there is a significant time lag between the polluting activity and the detection of the pollutant in groundwater. During this time, natural denitrification and volatilisation processes may reduce nitrate concentrations, in particular from the activity of denitrifying bacteria under favourable conditions.

Because of its anionic form, nitrate is very mobile in groundwater. The rate at which nitrates move through an aquifer is affected by the hydraulic parameters of the system and also other physical, chemical and biological processes. The recharge rate of an aquifer also influences the groundwater flow regime and hence the movement of nitrates. Alluvial and shallow aquifers are particularly vulnerable to nitrate pollution, whilst deep or confined aquifers are generally better protected. However, surface or near-surface outcrops of confined aquifers can allow nitrate to migrate towards deeper strata (EEA, 1999). The existence of deep boreholes that tap the entire sequence of successive aquifers create favourable conditions for the migration of nitrate polluted water from the surface or a superficial to a deeper confined aquifer (Panagopoulos, 1995).

Nitrate in drinking waters can present a health risk to humans, especially so to sensitive groups and infants. The consumption of waters with high concentrations decreases the oxygen capacity of blood (Kacaroglou and Gunay, 1997). Nitrate is transformed into nitrite in the digestive system, which causes methaemoglobinaemia. Infants and unborn babies are particularity at risk because of their low gastric acidity and undeveloped enzymatic system (Rajagopal and Tobin, 1989). Epidemiological studies have provided suggestive evidence relating dietary nitrate exposure to cancer, especially gastric cancer. It must be recognized that many factors in addition to environmental nitrate exposure may be involved (WHO, 1996).

The EU drinking water standard maximum admissible limit for nitrates is $50 \mathrm{mg}^{-1}$ (E.U. Council, 1998).

\section{NITRATE CONCENTRATIONS AND DISTRIBUTION}

As shown in Figure 3 nitrate concentrations in the studied area ranges from 1.2 to $524 \mathrm{mg} \mathrm{l}^{-1}$. Mean

\section{Frequency (courts)}

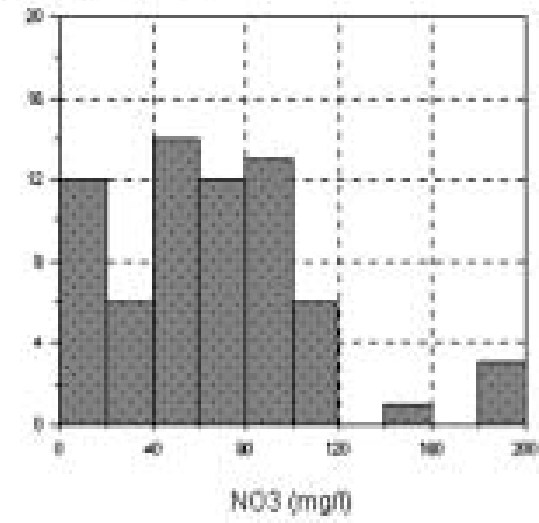

Figure 3. Distribution of $\mathrm{NO}_{3}$ concentration

nitrate concentration is $73.8 \mathrm{mg} \mathrm{l}^{-1}$ and the standard deviation 48.9. About $66 \%$ of the examined samples exceeded the maximum admissible concentration of $50 \mathrm{mg} \mathrm{l}^{-1}$ set by European Union for water intended for human consumption.

A close examination of the nitrate concentration distribution map (Figure 4) reveals that: Sites with noticeably higher concentration of nitrates occur in: (1) a zone extending near to Lecheo (northeastern part of the study area) and (2) a zone extending near to Zevgolatio (south central part of the study area). However the following remarks may be made: Highest concentrations of $\mathrm{NO}_{3}^{-}, \mathrm{K}^{+}, \mathrm{PO}_{4}^{3-}$ are concentrated in the northeastern part, as well as in the southern part, where extensive application of fertilizers to cultivation is known to be practiced. Low nitrate concentrations are observed in the southwestern part of the study area.

In the urban regions the high nitrate concentrations are attributed to the direct disposal of untreated domestic waste effluent in former wells that are presently used as septic tanks. In these areas high $\mathrm{NH}_{4}^{+}$concentrations are recorded, exceeding $0,5 \mathrm{mg} \mathrm{l}^{-1}$, which is the international drinking-water standard.

High Potassium and $\mathrm{PO}_{4}^{3-}$ concentrations were detected in most groundwater samples related to mixed-type fertilisers that contain nitrogen, phosphate and potassium (NPK).

Brackish waters that are also used locally for irrigation result in the reduction of plant nitrogen intake capacity. Farmers apply larger fertilization doses in order to overcome the problem, thus inducing an 


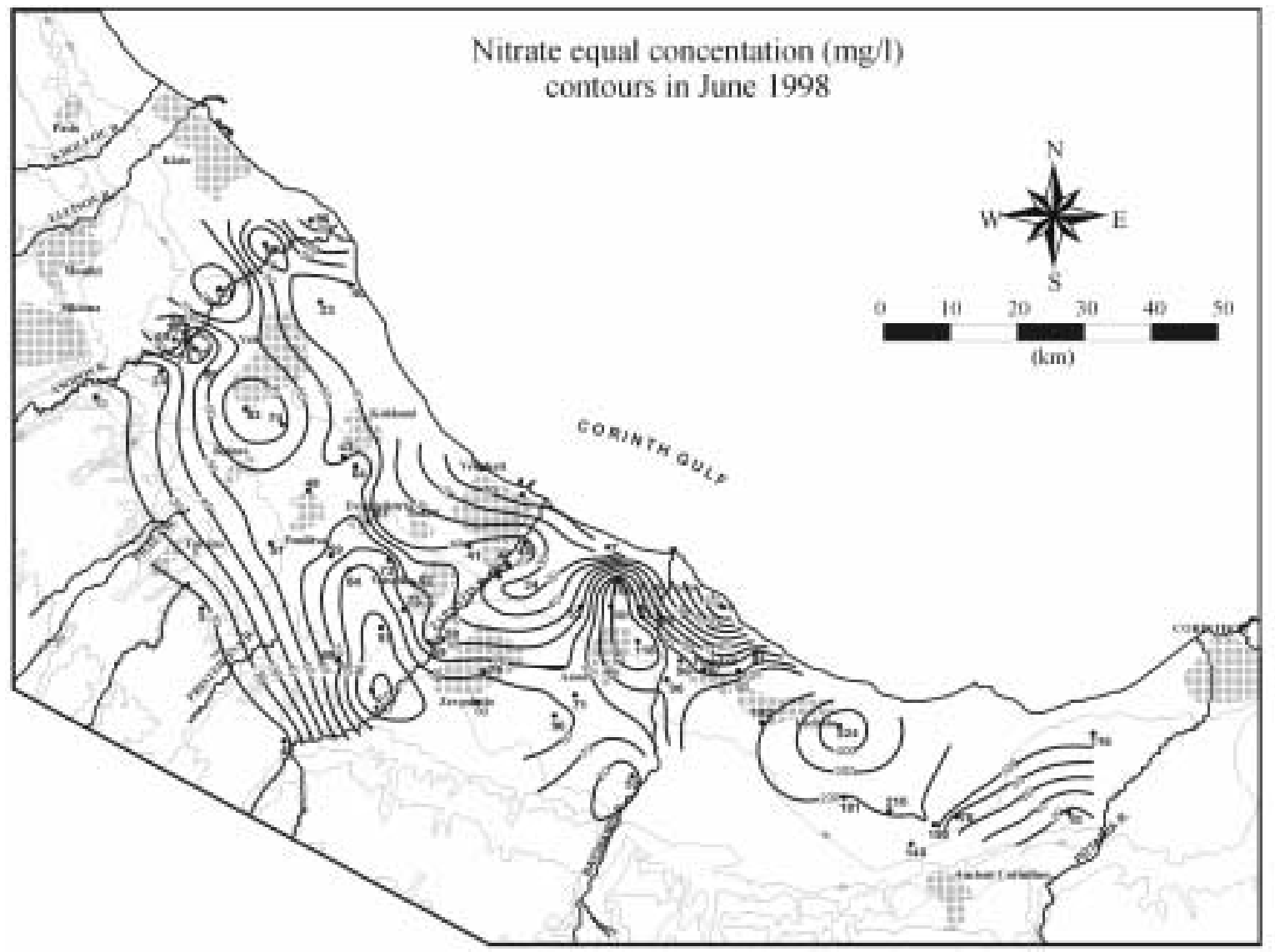

Figure 4. Areal distribution of $\mathrm{NO}_{3}$ concentration $\left(\mathrm{mg} \mathrm{l}^{-1}\right)$

extra source of groundwater pollution in the form of considerable nitrogen nitrates leachates.

Indicative of the extent of groundwater deterioration is the fact that in most of the areas, it is not suitable for human consumption on the basis of the nitrates content, whilst in considerable areas it is marginally acceptable even for irrigation, as deduced from the study of the hydrochemical composition (Panagopoulos et al., 2001). This condition is a result of the local hydrogeological setup, coupled with the traditionally applied flood irrigation, the over-fertilisation and the complete lack of environmental awareness regarding waste disposal. As illustrated in Figure 5 the highest concentrations are recorded in the dry season, due to the downward movement of shallow waters, which are high in nitrate, through the gravel pack of the production boreholes into the aquifer (Kacaroglou and Gunay, 1997). Higher temperatures in the dry season also favor nitrification of nitrogen ammonia retained in soil from septic tank effluent.

\section{Pollution attenuation}

Assuming complete cessation of nitrogen fertilization, the time $(\mathrm{t})$ required for decontamination of an aquifer is calculated from the following relationship (Yertsever, 1983; Lambrakis et al., 1997; Kallergis, 2000):

$$
t=\frac{t_{r}}{\ln \left(\frac{C}{C_{0}}\right)}
$$

where $t_{r}$ is the residence time, which is equal to $t_{r}=b \Theta / I, b$ is the aquifer thickness, $\Theta$ is its porosity and $\mathrm{I}$ is the aquifer's recharge. $\mathrm{C}_{0}$ and $\mathrm{C}$ represent the initial nitrates concentration and their concentration at a specific time $t$ after the cessation of fertilization respectively.

Based on the data of Table 2, application of this relationship under the assumption that the target background concentration of nitrates in groundwater is $15 \mathrm{mg} \mathrm{l}^{-1}$ after the cessation of fertilization, yields a mean attenuation time of $t=16.4$ years. 


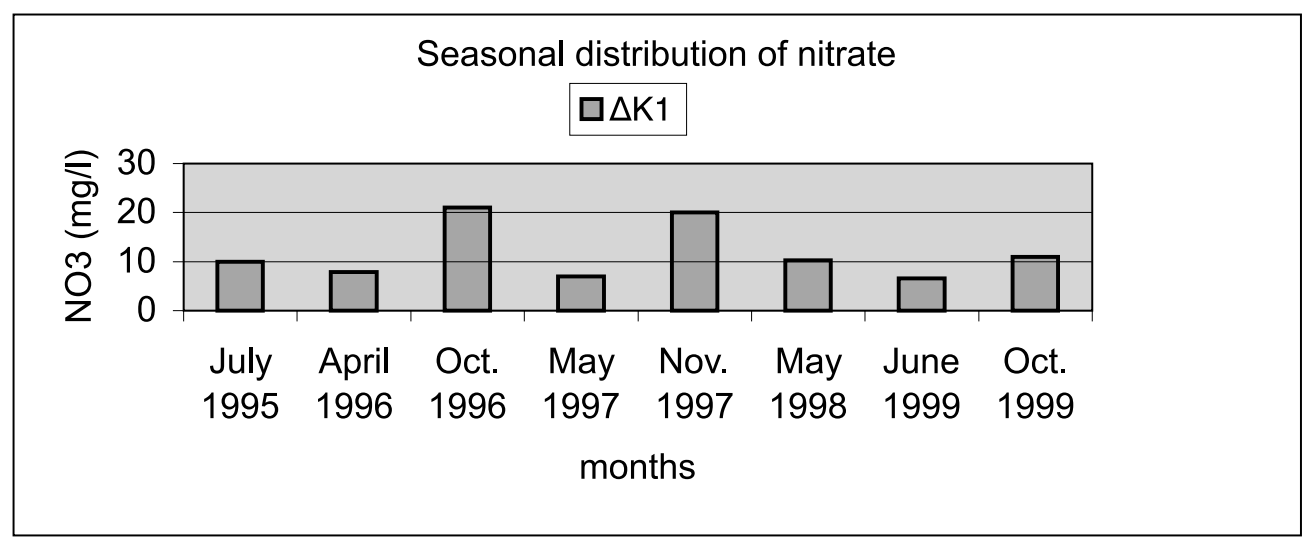

Figure 5. Seasonal variation of nitrate concentration

Table 2. Calculation of mean natural attenuation time

\begin{tabular}{|c|c|c|c|c|c|c|}
\hline $\begin{array}{c}\mathbf{b} \\
(\mathbf{m})\end{array}$ & $\boldsymbol{\Theta}$ & $\begin{array}{c}\mathbf{I} \\
(\mathbf{m})\end{array}$ & $\begin{array}{c}\mathbf{C} \\
\left(\mathbf{m g ~ L}^{-\mathbf{1}}\right)\end{array}$ & $\mathbf{t r}=\mathbf{b \Theta / I}$ & $\mathbf{I n}(\mathbf{C} / \mathbf{C o})$ & $\begin{array}{c}\mathbf{t}=-\mathbf{t r} / \mathbf{l n}(\mathbf{C} / \mathbf{C o}) \\
(\mathbf{y e a r s})\end{array}$ \\
\hline 25 & 0.1 & 0.095 & 74 & 26.3 & -1.6 & 16.4 \\
\hline
\end{tabular}

\section{CONCLUSIONS}

The study of the coastal alluvial aquifer system of Korinthos Prefecture, revealed extensive nitrates groundwater pollution attributed to several reasons, most important of which are the irrational application of fertilisation and irrigation doses and the use of septic tanks in conjunction with the disposal of untreated domestic effluent into abandoned wells. Average groundwater nitrate concentration exceeds $70 \mathrm{mg} \mathrm{l}^{-1}$, whilst much higher concentrations are documented at extensive parts of the region. Nitrate concentrations are higher in the dry season and progressively reduce in the wet season. Based on the average hydraulic parameters of the aquifer system it is calculated that a period of 16.4 years is required to restore groundwater quality to a background level of $15 \mathrm{mg} \mathrm{l}^{-1}$ nitrates, provided that complete cessation of fertilization is enforced.

In future the seasonal variation of the nitrate concentration should be recorded and a rational groundwater resources management policy should be designed on the basis of these results, in order to minimize the impacts of anthropogenic activities on the aquifer system. An action plan against groundwater pollution from nitrates should be compiled followed by a code for good agricultural practice. Such activities have already been applied in Greece, at basins with similar problems and have led to promising results in both environmental protection and restoration, without affecting the farmer's income (Karyotis et al., 2001a; Karyotis et al., 2001b). The action plan aims at ground and surface water protection from nitrates pollution. It is estimated that under this Plan a nitrate fertilisers application cut-down by at least $15-20 \%$ may be succeeded. The proposed reduction will be achieved by a series of measures amongst which are the effectiveness increase in fertilisation application, the introduction of alternative irrigation techniques, the optimisation of crop selection as a function of soil characteristics, groundwater artificial recharge and finally, a series of financial incentives.

\section{REFERENCES}

Antonakos A. and Lambrakis N. (2000), Hydrodynamic characteristics and nitrate propagation in Sparta aquifer, Water Res., 34, 3977-2000.

Daskalaki P., Voudouris K. and Diamantopoulou P. (1998), Hydrochemical study of North Peloponnesus quaternary and pliopleistocene aquifers, In: Proc. Int. Conf. Protection and Restoration of the Environment IV, Sani, Greece.

European Environmental Agency (1999), Groundwater quality and quantity in Europe, Enviromental assessment report, No 3 . 
E.U. Council (1998), Council directive 98/83 about water quality intended for human consumption, Official paper of the European Communities, V. L330, pp. 32-54.

Hill A.R. (1982), Nitrate distribution in the groundwater at the Alliston region of Ontario, Canada, Ground Water, 20, 696-702.

Hionidi M., Panagopoulos A., Koumantakis J. and Voudouris K. (2001), Groundwater quality considerations related to artificial recharge application in the aquifer of the Korinthos Prefecture, Greece, In: Proc. $3^{\text {th }}$ Int. Conf. Groundwater Quality 2001, Sheffield, United Kingdom, in press.

Freeze A. and Cherry J.A. (1979), Groundwater, Prentice Hall, Englewood Cliffs.

Kacaroglou F. and Gunay G. (1997), Groundwater nitrate pollution in the alluvium aquifer, Eskisehir urban area and its vicinity, Turkey, Environmental Geology, 31, 178-184.

Kallergis G. (2000), Environmental Applied Hydrogeology, Vol. B', Athens (in Greek).

Karyotis Th., Panagopoulos A., Danalatos N., Pateras D., Panoras A. and Kosmas C. (2001a), Agricultural policy to reduce nitrates in the ground water of central Greece, In: Proc. $2^{\text {nd }}$ Int. Workshop of the EU/INCODEV Concerted Action programme Enhancing Soil Fertility in Africa: from Field to Policy-Maker, "Beyond Nutrient Balances: The impact of research on processes of change in African agriculture", SOS Sahel, Adis Ababa, Ethiopia, pp.87-90.

Karyotis Th., Panagopoulos A., Kosmas C., Pateras D., Panoras A., Danalatos N. and Yassoglou N. (2001b), Guidelines for establishing a code for good agricultural practice in the river Pinios sedimentary basin, southern Greece, In: Proc. $12^{\text {th }}$ World Fertilizer Congress, Beijing, China. Preprints, Chinese Academy of Sciences, Beijing, China, in press.

Koumantakis J., Panagopoulos A., Stavropoulos X. and Voudouris K. (1999), Application of aquifer artificial recharge in the coastal alluvial basin of the northern part of Korinthos Prefecture, Peloponnese, In: Proc. $5^{\text {th }}$ Conf. on Hydrogeology, Nicosia, Cyprus, in press (in Greek).

Lambrakis N., Tiniakos L., Lazarou A. and Kallergis G. (1997), Nitrate pollution by agricultural activities in groundwater (Peloponnesus), In: Proc. $4^{\text {th }}$ Hydrog. Conf., Thessaloniki, p.p. 163-178 (in Greek).

Mikkelsen S. A. (1992), Current nitrate research in Denmark-background and practical application, nitrate and farming systems, Aspects of applied Biology, 30, 29-44.

Pacheco J. and Cabrera A. (1997), Groundwater contamination by nitrates in the Yucatan Peninsula, Mexico, Hydrogeology Journal, 5, 47-53.

Panagopoulos A. (1995), A methodology for groundwater resources management of a typical alluvial aquifer system in Greece, Ph.D Diss., The University of Birmingham, UK.

Panagopoulos A., Voudouris K., Koumantakis J. and Hionidi M., (2001), Groundwater evolution of the northern Corinthian region coastal aquifer system, as indicated by Hydrochemistry, In: Proc. $9^{\text {th }}$ Int. Conf. of the Geological Society of Greece, Athens, Greece.

Panagopoulos A., Voudouris K., Hionidi M. and Koumantakis J. (2002), Irrational water resources management impacts on the coastal aquifer system of Korinthia. In: Int. Conf. Protection and Restoration of the Environment VI, Skiathos.

Rajagopal P. and Tobin G. (1989), Expert opinion and groundwater quality protection: the case of nitrate in drinking water, Groundwater, 27, 835-847.

Rao S., Reddy T.V.K. and Nayudu P.T. (1997), Groundwater quality in the Niva river basin, Chittoor district, India, Environmental Geology, 32, 56-63.

Steinich B., Escolero O. and Marin L. (1998), Salt-water intrusion and nitrate contamination in the Valley of Hermosillo and El Sahuaral coastal aquifers, Sonora, Mexico, Hydrogeology Journal, 6, 518-526.

Voudouris K., Panagopoulos A. and Daniil D. (2000a), Implications to surface water quality of Korinthos Prefecture from anthropogenic activities, In: Proc. Int. Conf. Protection and Restoration of the Environment $V$, Thassos, Greece, 2000.

Voudouris K., Panagopoulos A. and Koumantakis J. (2000b), Multivariate statistical analysis in the assessment of hydrochemistry of the northern Korinthia Prefecture alluvial aquifer system, Peloponnese, Greece, Natural Resources Research, 9, 135-143.

WHO (1996), Guidelines for drinking-water quality, In: Health criteria and other supporting information, Vol. 2, Geneva.

Yurtsever Y. (1983), Models for tracer data analysis, In: Guidebook on nuclear techniques in Hydrology, IEEA, Vienna, pp. 381-402 